\title{
Chronic pain and substance use in patients with Hepatitis C
}

Ben Morasco

From $1^{\text {st }}$ International Congress on Neurobiology and Clinical Psychopharmacology

and European Psychiatric Association Conference on Treatment Guidance

Thessaloniki, Greece. 19-22 November 2009

The hepatitis $\mathrm{C}$ virus (HCV) is the most common blood-borne infection and affects approximately $2 \%$ of the U.S. population, with higher rates occurring in some segments of the population. Chronic pain affects approximately $35 \%$ of the general population, with $15 \%$ of individuals experiencing daily pain. In contrast, the prevalence of chronic pain among HCV patients may exceed $65 \%$.

The reasons for the high rates of chronic pain among $\mathrm{HCV}$ patients are not clear. More than two-thirds of $\mathrm{HCV}$ patients have a history of substance use disorder (SUD), and history of SUD is associated with the development of pain. HCV patients also have high rates of co-morbid psychiatric disorders, which are also associated with chronic pain.

The purpose of this presentation will be to outline the issue of chronic pain and substance use among $\mathrm{HCV}$ patients and to describe factors that may lead to the high rate of chronic pain in this patient population. The results of ongoing studies that examined the role of biopsychosocial factors in the development and exacerbation of chronic pain in HCV patients will also be described.

Published: 22 April 2010

doi:10.1186/1744-859X-9-S1-S81

Cite this article as: Morasco: Chronic pain and substance use in patients with Hepatitis C. Annals of General Psychiatry 2010 9(Suppl 1):S81.

Portland VA Medical Center, Portland, Oregon, USA
Submit your next manuscript to BioMed Central and take full advantage of:

- Convenient online submission

- Thorough peer review

- No space constraints or color figure charges

- Immediate publication on acceptance

- Inclusion in PubMed, CAS, Scopus and Google Scholar

- Research which is freely available for redistribution

Submit your manuscript at www.biomedcentral.com/submit
C Biomed Central 